\title{
Economic Empowerment Of Society Through Development Of Non-Formal Education Based On Life Skill Education In Pekanbaru City
}

\author{
Sabarno Dwirianto, M. Pudjihardjo, Susilo, Sasongko \\ Faculty of Economics and Business of Brawijaya University Malang 2014
}

\begin{abstract}
The purpose of this research is: 1) to analyze how the programs of society economic empowerment through non-formal education in Pekanbaru works, 2) to analyze whether economic empowerment of society through the development of non formal education has been successfully improving the economy of society.

The approach used in this research is case study using phenomenology perspective of qualitative research method. This research was conducted in Pekanbaru city. The subject of this research is the party which is involved in non formal education activity based on life skill education.

The result of this research is: 1) that life skill education in Pekanbaru city has various kinds. Generally, the program which has been programmed in a "package" could not match with the needs and wants of the society. (2) Non-formal education based on life skill education in Pekanbaru City could contribute to economy of the people who join this program. The impact occurs because the training which is given could develop and improve skills which affect the increasing of participant's productivity.
\end{abstract}

Keywords: Economic Empowerment, Non-Formal Education, Life Skill

\section{Introduction}

Human resources have an important role as the motor of the economic driver. Economic development should be enforced by the power of human resource which is devoted to God, has high work ethic, tough, independent, and has excellent professional skills. Planning, actuating, and evaluating of systematic development process could create and develop the power of human resource and so vice versa. Excellent human resource could ensure that the development process, which is happening, would become sustainable and could give a room of self empowerment for every development actor. Therefore, the essence of a development is to create empowered human resource to extend, develop, and continue the development process.

Beside formal education, another form of society economic empowerment is through the non-formal education. Non-formal education is an alternative and basic solution which is also efective to fulfill the need of education for Indonesian people. Nawipa (inside Giay, 1995) stated that non-formal education is one of solutions for Amungne, native tribe in Papua, to keep up with their backwardness. Non-formal education is predicted to become a priority for the society because of the incapability of formal education in keeping up with the modern science and technology in globalization era. This argument is based on the characteristic of globalization which is sudden and dynamic so that what subject studied eight years ago might be irrelevant in workplace, if we focus on working. Whereas, non-formal education is more applicable and responsive to the workplace and it is considered as a solution to the problem which is faced by the society.

Non-formal education find its momentum in a condition when the society is pragmatic, instant, and need high skills. Moreover, in lower economic society, what people think is about how to live for today. They learn to live and do not eager to study anything unpractical. Studying is for working and surviving from the result of the study. Thus, the people need to be encouraged to develop themselves through non-formal education based on the society, that is non-formal education which is formed by the people and applied for the people.

As a solution of the problem faced by the society especially to eradicate poverty and unemployment, non-formal education is focusing more on developing life skill based on the advantages of the village, city, and global areas. Life skill is a conception which means to give a person needed knowledge, skill, and functional qualification which can be described as personal, social, academic, and practical vocational skill. Moreover, enterpreneurship and profesionalism is essential in life skill concept. Thus, a person could work or open his own business by taking advantages from potential and opportunity in the neighborhood to improve his quality of life.

Some of the society empowerment programs are failing although there are some programs which could be considered successful. Some studies shows that there are some factors which affect the failure of those programs. Those factors are: (1) irrelevance of education given and the society needs, (2) lack of infrastructure, (3) insufficient planned monitoring, and (4) unavailability of institution to continue the project. Therefore, economic empowerment of society should be consistent with the education development of the society. This should be done in order to be able to reach the optimal goal (Sasono, 1998) 
Considering the various condition in Pekanbaru City, such as high level of unemployment, low education, and high poverty, a study of non-formal education development needs to be conducted to improve the economy of the people in Pekanbaru City.

\section{Literature Review}

\section{Human Investmen Theory}

Analysis model of education was built from a starting idea stating that education could increase one's income through the increase of productivity, so there will be a positive correlation between education and productivity. Some other views stating that education indirectly increase productivity. In this case, school is just considered as a "guarantee" that a person is considered having enough skill to complete a specific work. Education also classifies worker into two kinds: highly productive worker and low productive worker. Some workers who have low productivity do not have interest to improve their skills by getting more education because they think that education is an "expensive investment" as explained in the following picture 1:

\section{Picture 1}

\section{Decision to Get an Education}

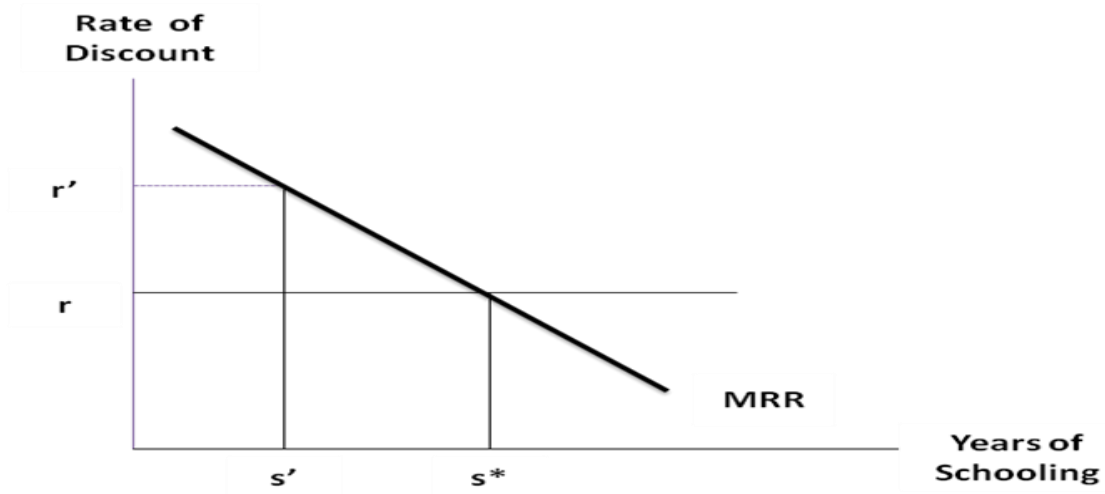

\section{Source: Borjas(2000)}

As shown in picture 1, MRR or marginal rate of return of schooling is explained as percentae of wage increase which comes from increasing year while going to school. Worker will maximize present value in all of their income by going to school until the rate of MRR is equivalent with discount rate. Worker with discount rate $r$ will chose school within $s^{*}$ year. It could be concluded that the higher the worker's level of education, which is shown by the increase of schooling year, has positive influence with the increase of wage. Borjas (2000) also explains some examples of govenrment programs which aim to improve the quiality of human resource. The first one is to give subsidy to training which is given to workers to improve their skills and the second one is to give school money as incentive for workers who want to continue their study.

\section{Human Capital Theory}

Human capital is a concept which was first developed by Theodore Shultz (1950, 1961, 1963, 1964, 1971) and Arthur Lewis (inside Becker, 1975) and then developed further by Gary Becker. The main idea of this research is formed capital, which is owned, such as bank account and owned share by individual is not enough. Labor skill, knowledge, and quality could also be considered as capital. Becket (1975) stated that expenses for education, training, medical treatment, etc are considered as investment in human capital. Based on these explanation, we can conclude that human capital is an asset related to intelectuality and someone's condition which is achieved from formal and non-formal education which are supported by good mental and physical health and ability to interract with other people to create beneficial and sustanaible relationship.

Emphasizing from human investment theory, it is stated that education is one of investment, which is invested to human. Besides it could also be an asset of one individual. Investment which is invested in the form of education is believed that it could improve one's capacity, not only intellectual and experience aspect but also skill. Skill which is earned from education could increase one's productivity which leads to the increase of one's income.

\section{Empowement Concept}


Conceptually, empowerment comes form the word "power". Because of that reason, the main idea of empowerment is close to the concept of power or authority. Power is often related to our ability to make others do what we want to achieve regardless their wants. Social traditional science emphasizes that power is related to influance and control. This meaning assumes that power as one that is not changing and also could not be changed.

This process is known as an empowerment process which enables other people to gain and use decision-making power (Schermerhorn, 2008). Empowerment is interpreted as a strategy to transfer decision making authority to the lowest high quality labor. This is the same as what Anthony, et al (2001) said that "Strategy of pushing the decision-making level down to the lowest level of qualified employees."

Person et al. (1994 in Suharto 2005) stated that empowerment process was generally done colectively and not personally between social labor and client in personal aid aspect. In social labor context, empowerment could be done in three empowerment settings, that is: micro, mezzo, and macro.

a. From Aras Mikro (Micro Level) aspect, the client of individual target is being empowered through guidance, stress management, and crisis intervention. The main purpose is to guide and train client in performing their activity.

b. Aras Mezzo (Mezzo Aspect), to a group of client, empowerment is performed by using groups as intervention media. Education, training, and also group dynamic are usualy used as a strategy in increasing knowledge awareness, skill and attitude of the client so that they have ability to solve their problems.

c. On the other hand, Aras Macro (Macro Level), which is also called as large system strategy because the objective is aimed to the larger environtment system.

In conceptual level, empowerment is closely related to social, economy, politic, and culture transformation (Mahmudi, 2002). Empowerment could be intrepreted as a process of power and self ability growing from society group which is low, marginalized, and suppressed. Empowerment process is assumed that even the lowest social group could be upraised to a part of middle class and high class This could be happened if they are given chance, offered help, and being facilitated by other partes that have commitment for it. Lower class group in one village for example, will not be able to empower themself without help or facitlity from other party. There should be a group of people, a person, or an institution, as an agent, to empower them.

\section{Research Approach}

The approach used in this research is case study using qualitative method specifically to the phenomenology perspective. Some reasons of using this approach are: 1) normally, case study uses basic questions what, how, and why so the objective of this reseach could be clearly and generally understood from the beginning. By using those three basic questions, research object, which is related to economic empowerment of the people by using non-ormal eduaction, could be gained maximally; 2) the researcher could not manipulate the occurence which is usually used in experimental research, 3) case study measures the real occurence by evaluating all of the proses of value crystalization within the informant or research object (Yin, 1994).

The reserach location is choosen using criterion based selection method. It is a selection based on specific criteria so that the background of all occurences could be well selected in order to get a complete information (LeCompte and Preissle in alwasilah, 2003; Kanto, 2003). This research was conducted in Pekanbaru City In which has sufficient level of non-formal education development compared with other cities and regencies in Riau Province. Non-formal educations in this city is also well developed not only in the urban area but also in the rural area.

The scope of this research is all phases and processes of non-formal education management which is facilitated by the government or privately implemented by the people themself in an institution such as BKPM or other similar institution which also focuses their activiy to empower society's economy through non-formal education.

\section{Function and Role of Non-Formal Education to Improve Human Resource in Pekanbaru City}

Based on education law No. 20 in 2003, non-formal education has a role to support lifetime education in order to develop the pontential of learners by emphasizing in mastering knowledge and functional skill, along with attitude development and social personality. Non-formal education is more focusing on reality and social life aspect, through some efforts to achieve a realization of learning process in the society. Non-formal education emphasizes more on the ability to face social problem in the environtment and to look for a right way to solve it, so that the society could improve their dignity and quality of life.

\section{Table 1}


Economic Empowerment Of Society Through Development Of Non-Formal

\begin{tabular}{l} 
Non-Formal Education Function \\
\begin{tabular}{|l|l|l|}
\hline No & Functions & Descriptions \\
\hline $\mathbf{1}$ & Supplementary Education & $\begin{array}{l}\text { an opportunity to increase/improve knowledge and specific } \\
\text { skill which is not taught in formal education }\end{array}$ \\
\hline $\mathbf{2}$ & Complementary Education & an opportunity to increase/complete education formal. \\
\hline $\mathbf{3}$ & Compensated education & $\begin{array}{l}\text { an opportunity to get an education for those who has never } \\
\text { received formal education. }\end{array}$ \\
\hline $\mathbf{4}$ & Substitute education & $\begin{array}{l}\text { an opportunity to learn in a speccific level of education due to } \\
\text { unavailability of school in the residence }\end{array}$ \\
\hline $\mathbf{5}$ & Alternative education & $\begin{array}{l}\text { an opportunity to select non-formal education according to } \\
\text { chances or the availabilityof time. }\end{array}$ \\
\hline $\mathbf{6}$ & $\begin{array}{l}\text { Enrichment/reinforcement } \\
\text { education }\end{array}$ & $\begin{array}{l}\text { an opportunity to enrich/widen/improve earned skills which is } \\
\text { earned from formal education. }\end{array}$ \\
\hline $\mathbf{8}$ & Forming education & $\begin{array}{l}\text { an opportunity to update or rejuvenate knowledge and skill } \\
\text { which are mastered }\end{array}$ \\
\hline $\mathbf{9}$ & Orientation edeucaiton & $\begin{array}{l}\text { an opportunity to gain new skill besides the skill which is } \\
\text { owned. }\end{array}$ \\
\hline $\mathbf{1 0}$ & Nursery education & $\begin{array}{l}\text { An opportunity to get an education of self orientation related } \\
\text { to territorial mobility, work, and social change. }\end{array}$ \\
\hline
\end{tabular} \\
$\begin{array}{l}\text { An opportunity to get an education or training of specific skill } \\
\text { through collective learning process while creating collective } \\
\text { business in a group. }\end{array}$ \\
\hline
\end{tabular}

\section{Source: Gitoasmoro (2005)}

The function of non formal education is to teach individual or group in order to be able to empower and develop themselves so that they could adapt to the globalization changes. Therefore, non-formal education is expected to be able to fulfill the needs of supplementary education, complementary education, compensatory education, substitution education, alternative education, enrichment education, updating education, orientation education, and nursery education.

Table 1 explains that non-formal education track is organized for the people who need education service as a substitution, supplementary, or complementary of formal education in order to support lifetime education. The function of non-formal education is to develop the potential of the learners by emphasizing in mastering knowledge and professional personality. Therefore, non formal education should not be underestimated by the society. Because of the importance of the role and function of non formal education will support national development.

Before advancing to further discussion about the relationship between non-formal education and society empowerment, this paragraph will explain the difference of non formal and informal education. Coombs and Ahmed (in Kamil, 2011) explains, that non formal education as every organized and systematical educational activity held outside formal education framework with the purpose of giving special learning material to some part of the society including children and adults. In lifetime education concept, informal education is an inseparable part with non-formal and formal education. The developed non formal and informal education institution in the society, it is difficult to identify and differ both of them.

The definition and concept of informal education is a process of lifetime education in which every individual gain and learn attitude, norm, skill, knowledge, and daily experience and influence from surrounding source of education such as family, neighbor, workplace, playing environment, shopping place, library, and mass media (Rogers. A in Kamil, 2011).

Based on the previous definition, we could understand that informall education is a process of unorganized and not systematical education which has a big impact to lifetime education of every people, including the high educated ones. In other words, informal education has a close relationship to the "learning with experience". Therefore, there is a deep meaning and close relationship between informal learning and informal education although it is so difficult to define both of them. It is because that informal education is not organized and also a life time learning. Thus, talking about informal education is also talking about informal learning.

Development is a process toward a better way by using all sources available. One of the colors which animate the development planner in Indonesia is the unwillingness to think comprehensively about human which is also the aim and the actor of development process. Although the paradigm of development has changed, the program implementation of it has not shown any result. As an example, the concept about the nature and meaning of development has shifted from striving for economic development with an expectation that there will be an effect of droplets and distribution to the sides from the direction of development paradigm of equity to the 
most trustworthy paradigm of human development. This paradigm is only resounding in the conceptual level, but the implementation in the form of program which reflects the soul of the paradigm itself is still peripheral and far from the expectation. The kinds and ways to handle the development program in 1970s are still being used and have only a few adjustments in the first decade of $21^{\text {st }}$ century.

The first Human Development Report (HDR) in 1990 defined human development as a process to make humans have variety of choices. Income is one of the choices that humans have, but not a totality of all aspect in humans' life. Health, education, good environment, and free hand are also important. Anwar and Haryadi (2004) said that development of the society especially in the poor society is a chain of activity to increase asset and ability of the people to be able to access resources, capitals, technologies, and markets with mentoring approach, improvement in capacity, service, and advocacy towards the autonomy of the people.

Based on the previous explanation, it could be seen that society empowerment is better performed through non-formal education. Non-formal education in Riau Province could reach some aspects which has been stated before, so that this empowerment could improve the independence of the pople and increase their wealth later on. The function of monitoring and motivating is very important to succeed this program because based on this conception and empowerment themselves it has basic understanding not to let "outsiders" take part as "trainers" or "insturctors" but let them take part as a facilitator in this society empowerment. Facilitator is a companion who has some functions to ease, motivate, and facilitate social group to empower themselves.

The government, through the ministry of education in 2011, provided some service programs such as basic literacy education, independent business literacy, family literacy, and literacy based on local art and culture. These programs were supported by the help from Taman Bacaan Masyarakat Rintisan (Pilot of Public Reading), Taman Bacaan Masyarakat Penguatan Keaksaraan (Public Reading of Literacy Reinforcement), and Taman Bacaan Masyarakat Ruang Publik (Public Reading of Public Space), and also education programs for women empowerment such as women life skill education, improvement of writing culture through Koran Ibu (Mother's Newspaper), women empowerment education for sustainable development, home education with the conception of gender, and other similar programs.

Non-formal education with its various programs offered has a main goal of economic empowerment through society economic empowerment, so that the people could develop their skills which are expected for the society to be able to get a job with their owned skills. Furthermore, the people could also create a new work field with their skills which could decrease the number of unemployment

The improvement of the quality of education is expected to give opportunity of higher growth in the future because by improving education, labors will have a better skill in operating and exploiting modern economic resources. Campbell and Stanley (1986) stated that investment of human capital is all activities which aim to improve the quality (productivity) of labors on the specific time. Investment of human capital could be performed by formal education and training given within work period.

Table 2 Curriculum of Non-Formal Education Based on Life Skill

\begin{tabular}{|c|c|c|}
\hline Program & The First Three Months & The Second Three Months \\
\hline $\begin{array}{l}\text { Tailoring } \\
\text { Course }\end{array}$ & $\begin{array}{ll}\text { Basic } & \\
\text { In this step students are going to learn: } \\
\text { 1. } & \text { Creating pattern } \\
2 . & \text { Cutting materials } \\
\text { 3. } & \text { Tailoring work } \\
\text { 4. } & \text { How to measure } \\
5 . & \text { How to cut the materials } \\
6 . & \text { How to sew } \\
7 . & \text { Finishing }\end{array}$ & $\begin{array}{l}\text { Skilled } \\
\text { In this step students are going to learn : } \\
\text { 1. Model rupture in skilled level } \\
\text { 2. Clothes pattern }\end{array}$ \\
\hline $\begin{array}{l}\text { Automotive } \\
\text { Training }\end{array}$ & $\begin{array}{l}\text { 1. Engine Electric } \\
\text { a. Engine system } \\
\text { b. Filling system } \\
\text { c. Starter system } \\
\text { 2. Engine Overhoule } \\
\text { a. Top overhouler } \\
\text { b. Full overhoule } \\
\text { 3. Fuel System } \\
\text { 4. Chasis } 1 \\
\text { a. Clutch } \\
\text { b. Manual transmission } \\
\text { c. Wheel and axle shaft }\end{array}$ & $\begin{array}{l}\text { 1. Chassis } 2 \\
\text { a. Brake system } \\
\text { b. Steering system } \\
\text { c. Wheel geometry and suspense } \\
\text { d. Wheel and tire } \\
\text { 2. Body electrical system } \\
\text { a. Head lamp, turn lamp, brake lamp, } \\
\text { reversing lamp, weeper motor, fog light, etc } \\
\text { b. Power window, central lock, and car alarm } \\
\text { 3. Tune up and engine troubleshooting } \\
\text { 4. Chassis troubleshooting } \\
\text { 5. AC } \\
\text { 6. EFI }\end{array}$ \\
\hline
\end{tabular}




\begin{tabular}{|c|c|c|}
\hline Program & The First Three Months & The Second Three Months \\
\hline & & $\begin{array}{ll}\text { a. } & \text { EFI Tune UP } \\
\text { b. } & \text { EFI Troubleshooting }\end{array}$ \\
\hline AC Repair & $\begin{array}{l}\text { 1. Understanding of } \mathrm{AC} \text { and its } \\
\text { applications. } \\
\text { 2. Components of } \mathrm{AC} \\
\text { 3. Process and principal on } \mathrm{AC} \text { working } \\
\text { system. } \\
\text { 4. Natural refrigerant and synthetic } \\
\text { refrigerant } \\
\text { 5. Retrofiting, charging, and recovery } \\
\text { process } \\
\text { 6. Introduction of AC repair equipment } \\
\text { 7. Practical work of AC system } \\
\text { introduction }\end{array}$ & $\begin{array}{l}\text { 1. Ozone damage and global warming } \\
\text { 2. Air comfort temperature, humidity, air } \\
\text { cleanliness of AC } \\
\text { 3. AC troubleshooting } \\
\text { 4. AC electrical system } \\
\text { 5. Practical work of retrofitting, charging, } \\
\text { and recovery } \\
\text { 6. Practical work of AC performance } \\
\text { measurement. }\end{array}$ \\
\hline $\begin{array}{l}\text { Screen } \\
\text { printing }\end{array}$ & $\begin{array}{l}\text { 1. Design concept: design element, } \\
\text { composition, color, and element } \\
\text { 2. Introduction to the tools: corel, } \\
\text { photoshop } \\
\text { 3. Design resource: design element, font, } \\
\text { silhouette, splatter, brush, clipart, } \\
\text { grunge } \\
\text { 4. Tracing technique } \\
\text { 5. Color separation technique }\end{array}$ & $\begin{array}{l}\text { 1. CMYK Technique } \\
\text { 2. T-shirt design } \\
\text { 3. T-shirt mock up } \\
\text { 4. Production process: material, screen } \\
\text { printing, tailoring, cut make trim } \\
\text { 5. Marketing }\end{array}$ \\
\hline Soap Making & $\begin{array}{l}\text { 1. Theory of soap making } \\
\text { 2. Introduction of nature and function of } \\
\text { each liquid soap material } \\
\text { 3. Preparation: materials and tools } \\
\text { 4. Liquid soap making }\end{array}$ & $\begin{array}{l}\text { 1. Cost analysis } \\
\text { 2. Marketing }\end{array}$ \\
\hline $\begin{array}{l}\text { Tissue Box } \\
\text { Making }\end{array}$ & $\begin{array}{l}\text { 1. Theory of tissue box making } \\
\text { 2. Introduction of tools and function of } \\
\text { tissue box making and cover decoration } \\
\text { 3. Preparation: tools and materials } \\
\text { 4. Tissue box making }\end{array}$ & $\begin{array}{l}\text { 1. Cost analysis } \\
\text { 2. } \text { Marketing }\end{array}$ \\
\hline Hairstyling & $\begin{array}{l}\text { 1. Basic theory of hairstyling } \\
\text { a. Shampooing } \\
\text { b. Creambath } \\
\text { c. Hair spa } \\
\text { d. Hair mask } \\
\text { e. Blow dry } \\
\text { 2. Theory of hairstyling } \\
\text { a. Hair cutting } \\
\text { b. Hair curling } \\
\text { c. Styling } \\
\text { d. Hair polishing } \\
\text { e. Hair bun } \\
\text { f. Basic coloring } \\
\text { g. Basic rebounding }\end{array}$ & $\begin{array}{l}\text { 1. Advanced theory of hairstyling } \\
\text { a. Hair trim design } \\
\text { b. Curling design } \\
\text { c. Coloring } \\
\text { d. Rebounding } \\
\text { e. Hair bun design }\end{array}$ \\
\hline Make up & $\begin{array}{l}\text { 1. Theory of make up } \\
\text { a. Face cleaning } \\
\text { b. Nose shading } \\
\text { c. Powder sowing } \\
\text { d. Eye shadow } \\
\text { e. Eyebrow threading } \\
\text { f. applying blush on } \\
\text { g. Making lips line and applying lipstick } \\
\text { h. Eyelash clamping } \\
\text { 2. Theory of Hair Bun } \\
\text { a. Combing hair techniques }\end{array}$ & $\begin{array}{l}\text { 1. Theory of dressing wedding costume } \\
\text { a. How to wear wedding costume } \\
\text { b. How to apply accessories, flowers, etc. }\end{array}$ \\
\hline
\end{tabular}


Economic Empowerment Of Society Through Development Of Non-Formal

\begin{tabular}{|l|l|l|}
\hline Program & The First Three Months & The Second Three Months \\
\hline & $\begin{aligned} \text { b. Creating hair bun techniques } \\
\text { c. Applying accessories techniques }\end{aligned}$ & \\
\hline
\end{tabular}

Source: Ministry of Education in Pekanbaru City, 2011

From the curriculum shown in table 2, it shows that there are a lot of advantages which are received by the people when they enroll in non-formal education based on life skill. Curriculum which is offered is basically aimed to improve skills and abilities of the participant. It is shown from the tailoring course in the curriculum which explains all steps from making pattern to tailoring process and finishing.

Non-formal education with its variety of programs has a main objective to empower economy through society economic empowerment, so that the society could develop their skill which is expected to be useful for getting a job. Moreover, the people could also create a new work field by their skill which could decrease the number of unemployment.

\section{The Implication of Human Resource Quality Improvement through Life Skill Training to the Increase of Labor Productivity}

Empirical studies in some countries which was conducted by Barro (1991,1998), Mankiw, et al (1991), Nelson and Pack (1998) elaborate that the level of education is usually measured by the percentage of high educated labor to the number of labor or enrolled citizen in a specific level of education (Tambunan, 2001). In the other hand, Engelbrecht (2003) stated that higher investment in human capital and accumulation or formation of physical capital causes America to be able to gain a sustainable economic growth. Furthermore, from some literature studies of economics, it could be known various functions of human capital which is useful to increase the individual income and as a motor of economic growth.

As explained in the previous chapter, non-formal education is not only focusing on the literacy but also implementing the training activities as one of the important part of non-formal education. The main objective of skill training is to improve the quality of human resource so that they could gain a higher value when they become a labor in an enterprise. The direction of training program is to give various skills to the learners to go to work or open their own business. As Nuraini (55) who is manager of Community Learning Center (PKBM) Pelita Riau, stated

“...So far, PKBM which I established aims especially for equalization learners so when they graduate they will have higher skills, then it will be easier for them to get a job and compete in the labor market. Because I think, if they only have equalized certificate they would find difficulties in finding a job, but if they get a skill they will get more skill. So if they could not get a job by using equalized certificate they could open their own business using the skills they have."

Most people who come to the informal institution would like to improve their potential which has not been developed in formal education such as beauty course, tailoring, mechanic, computer, etc. Learners come to course institutions with the intention of having skills which have not be taught in formal institution. Considering the function of non-formal education, course institution as stated on the example is considered as complementary to non-formal institution.

The function of non-formal education institution is not much different to formal education which is to transfer knowledge to learners. Not only as a place to gain knowledge, but non-formal institution is also used as a place to improve skills of the learners. Therefore, there are many non-formal institutions which are established to train basic skills.

So far, the program which is offered by PKBM is a program demanded by the society and needed by the labor market. However, the society's demand could change in a sudden as explained by Mr. Devrizal about agriculture training. The difficulty of the government to create employment for the people is because of the increase of the number of citizen from year to year. This problem would also worsen because the skills of the citizen are limited so there will be more people become unemployed. The problem of creating employment in the rural area is the economic condition is limited working capital infrastructure, skill, and marketing. This means that the complexity of this problem could not be solved with only one facility, for example by giving loan. The more important thing is by giving them skill so they have skill to improve their economic condition.

The example of the effect of non-formal education to the increase of income was obtained from Mr. Zulkifli, a learner from PKBM which is managed by Mr. Bayan.

"...there is one of my students who actively involved in some activities with me in making screen printing of invitation, pamphlet, and banner. Usually, he works as a city transport driver, but now he is not only working as a city transport driver but also getting income from designing invitation, pamphlet, and also banner."

In Pekanbaru City, there are various kinds of non-formal institution which functioned as complementary institution. Some LPK (Leadership Development Institute) in Pekanbaru City are functioned as complementary institution. Some programs are offered to fulfill the potential of the learners. There are 
institutions which provide programs such as bridal make up, hairstyling, spa, and other things related to beauty. There are some mechanics institutes which offer car mechanics and driving program. There are still many institutions which could complete the knowledge of the learners so the underdeveloped potential could be developed.

As said by Zulkifli (21) learners from institution which is managed by Mr. Bayan:

"... I am a city transport driver. The income I make is not high enough especially these days. The passenger is somewhat few. And then I was invited to join a course to make screen print by Mr. Bayan. And now I can make screen print. So in the afternoon I work as a driver and in the evening I work as a screen print maker and make pamphlet. My income has increased more than when I worked only as a driver."

Based on Zulkifli's statement, we could infer that the training which is got form life skill institution is really affecting his income, so there is difference before and after joining the training. According to Zulkifli, his skill after training could be used as a side job. There are some differences in skill and income before and after informant joining the empowerment program.

The final objective from an empowerment especially in economic area is to increase the income of low income people. The income of the people generally comes from two sources that are wage/salary and profit. The wage/salary of "helpless" people is so low because of their low skill. The low skill is owned because of the difficulty to access and get chance to get a better education.

Not only a few learning residence who can be successful in business by enrolling life skill training. As stated by Ahmad (22) a learner from PKBM Insan Cendekia:

"... I enrolled in AC reparation course because I like it and I want to know about it, so I diligently join the course. Now, I can open my own AC reparation business. I could add more reasonable income. When I haven't joined the course, I worked in AC Reparation shop, but since I have the required skill, now I open my own business."

Form the statement above, it could be inferred that non-formal education was conducted to help the learners improving their skills so that they could improve their life quality. As stated by Sudjana (1998) explained that the role of non-formal education are: (a) to make learners learn so they have and be able improve their skill, knowledge, attitude, values, and aspiration to anticipate the future change, (b) to make learners learn so they can improve and utilize resources to improve their life. Human investment is a way to increase the value of "goods and services" which is produced later on, so that the economical value could develop through a process of adding value such as improvement of attitude, knowledge, ability, expertise, and skill.

Participation of learners has a very big role in empowerment process. The Statement of success story from Ahmad who is used to work in AC repair store and now he could open his own AC repair business after learning skills related to $\mathrm{AC}$ repair. It becomes the final objective of empowerment process, from "nothing" to "something". There are a lot of changes that could be got. Especially from economic side, there will be an increase of income and there will be an increase in standard of living in micro scale. While in macro scale, there will be more employment for the people.

\section{Conclusion}

Based on the observation on the field, the implementation of economic empowerment in the society through non-formal education based on life skill education in Pekanbaru City could be deduced in this following conclusion.

1. Economic empowerment of the society through non-formal education based on life skill education in Pekanbaru City has many varieties. Generally, the program has been "packaged" so it cause inconsistence between the program and the people's wants and needs.

2. Non-formal education based on life skill in Pekanbaru city could give a good impact to the economy of some people who enrol this program. This impact occurs because of the training given could develop and improve skills which affect the productivity of the participants.

\section{Bibliography}

[1] Al Wasilah, A. Chaedar. (2003). Pokoknya Kualitatif: Dasar-dasar Merancang dan Melakukan Penelitian Kualitatif. Jakarta: Pustaka Jaya

[2] Barro, Robert J., 1998, Human Capital and Growth in Cross Country Regressions, Journal of Economics, Jurnal of Economics Harvard University No. 214.

[3] Becker, GS. 1975. "investment in Human Capital: Effects on Earnings, "NBER Chapter, in: Human Capital: A Theoretical and Empirical Analiysis, with Special References to Education, 2 nd ed., pages 13-44 National Bureau of Economics Research, Inc.

[4] Borjas, George J. 2000. Labor Economics Second Edition. A Division of the McGraw-Hill Companies.

[5] Engelbrecht Hans-Jurgen. 2003. Human Capital and Economic Growth Cross-section evidence OECD Countries. Journal Economic Record. East Ivanhoe. Vol 79

[6] Giay, B. 1995. DR Nawipa : Pendidikan Nonformal Dapat Merubah Kebudayaan Orang Amungme Yang Berporoskan Hai. Deiyai. Majalah Informasi Agama Dan Kebudayaan Irian Jaya. Edisi Perdana September - Oktober 1995. Halaman 3 - 5

[7] Kamil, Mustofa. 2011. Pendidikan Non Formal, Pengembangan Melalui Pusat Kegiatan Belajar Mengajar (PKBM) di Indonesia (Sebuah Pembelajaran dari Kominka, Jepang). Bandung. Alfabeta. 
[8] Mankiw, N Gregory, David Romer and David N.Weil. 1992. "A Contribution to The Empirics of Economic Growth", Quartely Journal of Economics, May

[9] Nawipa, N. 1995. Pendidikan Non Formal: Sarana Dialog Dalam Proses Integrasi Nilai-Nilai Budaya Suku Bangsa Amungme di Irian Jaya. Deiyai. Majalah Informasi Agama Dan Kebudayaan Irian Jaya. No.2/Thn.1 November - Desember 1995. Halaman 6 10

[10] Sudjana, D (2001), Pendidikan Luar Sekolah: Wawasan, Sejarah Perkembangan, Falsafah \& Teori Pendukung, serta Asas, Bandung; Falah Production.

[11] Tambunan, Tulus. 2001. Krisis Ekonomi dan Masa depan reformasi. Lembaga Penelitian FE-UI. Jakarta.

[12] Yin, R. (1994). Case study research: Design and methods (2nd ed.). Beverly ills, CA: Sage Publishing. 